\title{
Experimental studies of different quenching media on mechanical and wear behavior of $\mathrm{Al7075} / \mathrm{SiC} / \mathrm{Al}_{2} \mathrm{O}_{3}$ hybrid composites
}

\author{
M. Ravikumar \\ Department of Mechanical Engineering, R L Jalappa Institute of Technology, Bangalore (R), Karnataka, India \\ ravik.umar.muk@gmail.com
}

H. N. Reddappa

Department of Mechanical Engineering, Bangalore Institute of Technology, Bangalore, Karnataka, India

reddybn.phd@gmail.com

\section{R. Suresh*}

Department of Mechanical and Manufacturing Engineering, M.S. Ramaiah University of Applied Sciences, Bangalore-560058, Karnataka, India.

sureshchiru09@gmail.com

\section{Sreenivasa Reddy}

Department of Mechanical Engineering, R L Jalappa Institute of Technology, Bangalore (R), Karnataka, India sreenivasam123@gmail.com

ABSTRACT. The effects of $\mathrm{SiC}$ (Silicon Carbide) - $\mathrm{Al}_{2} \mathrm{O}_{3}$ (Aluminium Oxide) particle in the $\mathrm{Al}$ alloy on the mechanical and wear characteristics of stir-casted Composites have been reported. The Al7075 is reinforced with 2, 4, 6 and 8 wt. $\%$ of reinforcements $\left(\mathrm{SiC}+\mathrm{Al}_{2} \mathrm{O}_{3}\right)$ to manufacture the hybrid composite. Ceramic particulates were added into $\mathrm{Al}$ alloy to achieve the low wear rate and improved mechanical properties. Hardening of cast specimens was done at $480^{\circ} \mathrm{C}$ for the duration of $2 \mathrm{hrs}$ and the specimens were quenched into two different quenching media (water and ice cubes). Finally, age-hardening was carried out at the temperature of $160^{\circ} \mathrm{C}$ for the duration of $4 \mathrm{hrs}$ and cooled at room temperature. The tensile strength, hardness and wear behaviour of MMCs (metal matrix composites) were evaluated on the un-treated and heat treated composite. The tensile strength and hardness of MMCs increased by incorporating $\mathrm{SiC}-\mathrm{Al}_{2} \mathrm{O}_{3}$ particulates. The wear behaviour of the MMCs containing $\mathrm{SiC}-\mathrm{Al}_{2} \mathrm{O}_{3}$ particulates revealed high wear-resistance. The heattreatment had considerably improved the properties when compared to the non-heat treated composites. The composites with the highest tensile strength, hardness and enhanced wear resistance were found in the composites quenched in ice cubes. Worn-out surfaces of the composite

\section{OPEN ACCESS}

Citation: Ravikumar, M., Reddappa, H.N., Suresh, R., Sreenivasareddy, M., Experimental studies of different quenching media on mechanical and wear behavior of $\mathrm{Al} 7075 / \mathrm{SiC} / \mathrm{Al}_{2} \mathrm{O}_{3}$ hybrid composites, 55 (2021) 20-31.

Received: 27.07 .2020 Accepted: 16.10 .2020 Published: 01.01.2021

Copyright: (C) 2021 This is an open access article under the terms of the CC-BY 4.0, which permits unrestricted use, distribution, and reproduction in any medium, provided the original author and source are credited. 
specimens were studied by using SEM (Scanning Electron Microscopy) and

EDS (Electron Dispersion Spectroscopy) analyses.

KEYwORDS. Al 7075; MMCs; Heat treatment; Tensile; Hardness; Wear rate.

\section{INTRODUCTION}

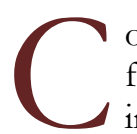

omposites, "materials in which two or more constituents are combined to create a material with properties different from that of either constituent," have been in existence for 1000 of years. Al-based MMCs are a valuable addition in the area of newer materials for a high performance application. The composites have better properties than the matrix. The properties include abrasion resistance, improved thermal conductivity, tribology, dimensional stability, creep resistance and good stiffness [1]. Interpretation of the materials is generally subjected to optimal choice of reinforcing materials. Ceramic particulates can be reinforced into light metal alloys like aluminium $(\mathrm{Al})$, copper $(\mathrm{Cu})$, zinc $(\mathrm{Zn})$, magnesium $(\mathrm{Mg})$ and stainless steel for additional weight reduction. The hard ceramic particulates such as $\mathrm{Al}_{2} \mathrm{O}_{3}, \mathrm{SiC}, \mathrm{MgO}$, $\mathrm{SiO}_{2}$ and $\mathrm{B}_{4} \mathrm{C}$ in the aluminium matrix alloy are frequently used as reinforcement materials to improve its mechanical properties [2]. The possible responses between the ceramic particulates and the $\mathrm{Al}$ alloy at high temperatures are very essential. This phenomenon has a substantial effect on the stipulations of the interface and second phase. It is clear that, a better bonding at the interface among the reinforcements and the base matrix has a considerable impact on mechanical behaviour of the MMCs [3]. Due to its significant strength-to-density, weight ratio, high modulus, wear resistance, strength values, and easy availability, ceramic particles can be used as reinforcement particles in composites [2]. Ceramic compounds like $\mathrm{SiC}, \mathrm{Al}_{2} \mathrm{O}_{3}$, etc., and carbon allotropes can be used to reinforce $\mathrm{Al}, \mathrm{Mg}, \mathrm{Cu}$ and alloys [4]. Among other parameters, wt. $\%$ of $\mathrm{Al}_{2} \mathrm{O}_{3}$ and $\mathrm{SiC}$ can influence mechanical properties of $\mathrm{Al}$ MMCs. Incorporating of $\mathrm{Al}_{2} \mathrm{O}_{3}$ to $\mathrm{Al}$ shows enhancement of mechanical and tribological properties in composites [5]. Addition of $\mathrm{Al}_{2} \mathrm{O}_{3}, \mathrm{SiC}$ and $\mathrm{B}_{4} \mathrm{C}$ particulates reinforced in $\mathrm{Al}$ will enhance the mechanical and tribological behaviour and ductility reduces. The wt. \% of reinforcements $\left(\mathrm{Al}_{2} \mathrm{O}_{3} \& \mathrm{SiC}\right)$ and heat-treatment for enhancing the mechanical and tribological properties of composites were reported. As compared to monolithic alloy, addition of hard reinforcements such as $\mathrm{Al}_{2} \mathrm{O}_{3}, \mathrm{TiC}, \mathrm{B}_{4} \mathrm{C}$ and $\mathrm{SiC}$ to matrix alloy enhance the hardness and reduces the wear rate [6]. Reinforcing $\mathrm{Al}$ alloys with ceramic particulates such as $\mathrm{SiC}$ or $\mathrm{Al}_{2} \mathrm{O}_{3}$ causes a considerable improvement in mechanical properties over conventional $\mathrm{Al}$ alloys, like improving strength and wear resistance. Though, these reinforcements have considerably reduced ductility when compared to alloys [7]. Al composite processing method entails using of $\mathrm{Al}$ as the matrix with adding particles to form MMCs. It is revealed that, the conventional processing methods such as stir casting, powder metallurgy, spray deposition process, vacuum hot pressing and squeeze casting methods can be adopted for the fabrication of composites [1]. The liquid metallurgy method is a good inexpensive technique for fabrication of MMCs. By the various liquid metallurgy procedures stir casting method can be utilized for production of ceramic particulates reinforced hybrid composites [2]. The stir casting technique is chosen because it is simple and economical and also it can be easily monitored [1]. Composites fabricated by stir casting method have certain advantages such as faster manufacturing rate and near net shapes can be achieved when compared to solid state methods [8]. Subramanya Reddy et al. [9] researched on Al MMCs produced by the stir casting method with varying wt. \% of silicon carbide and boron carbide. Mechanical properties were studied and it was revealed that the hybrid MMCs had better properties as compared to pure $\mathrm{Al}$ due to the existence of the carbide particles in the composite. Rajesh and Sudhir [10] researched on $\mathrm{Al}-\mathrm{SiC}$ reinforced composites. The results concluded that the silicon carbide particles form barricades which hinder the dislocation motion. This supports to enhance the tensile strength and hardness of MMCs. Manoj Singla et al. [11] researched on the hardness of $\mathrm{SiC}$ reinforced metal matric composites. Various wt. \% of $\mathrm{SiC}(5 \%, 10 \%, 15 \%, 20 \%$, $25 \%$ and $30 \%$ ) were adopted to produce MMCs by stir casting method. The outcomes revealed that the hardness in the MMCs enhanced with increase in the wt. \% of SiC particles. Sharma et al [12] studied the effect of $\mathrm{SiC}$ reinforcement on wear behavior of ZA27 alloy MMCs. The results revealed that unreinforced alloy have higher wear rate when compared to composites and by increasing wt. \% of reinforcements, the wear rate decreased. The increase in hardness and comparatively high percentage of elongation which leads to work hardening seems to be responsible for increase in UTS (Ultimate Tensile Strength) of $\mathrm{Al}_{-} \mathrm{Al}_{2} \mathrm{O}_{3}$ MMCs [13]. The fabrication of $\mathrm{Al}$ composites with different weight percentages of $\mathrm{Al}_{2} \mathrm{O}_{3}$ particles was processed by liquid metallurgy route. It revealed that the $\mathrm{Al}_{-} \mathrm{Al}_{2} \mathrm{O}_{3}$ composites have a higher tensile strength than aluminium alloy with reduced ductility. It was found that an increase in the $\mathrm{Al}_{2} \mathrm{O}_{3}$ content in $\mathrm{Al}$ alloy contributed to enhancing the hardness of the composites [14]. Surappa and Rohatgi [13] studied the mechanical properties of $\mathrm{Al}$ alloy reinforced by $\mathrm{Al}_{2} \mathrm{O}_{3}$. It was found that the increase in hardness of MMCs might be attributed to the comparatively high hardness of alumina compared with aluminium. Yllmaz and Buytoz [6] researched on the wear characteristics of $\mathrm{Al}_{2} \mathrm{O}_{3}$ 
reinforced aluminum MMCs. The results revealed that the wear rates decreased rapidly by increasing the wt. \% of $\mathrm{Al}_{2} \mathrm{O}_{3}$. Abdel-Azim et al. [15] in his research, applied vortex method process to produce $\mathrm{Al}-\mathrm{Al}_{2} \mathrm{O}_{3}$ composites. It was revealed that the addition of alumina particles improved the wear resistance and also increased the COF (Coefficient of Friction). The improvement in the wear behaviour of $\mathrm{Al}_{-} \mathrm{Al}_{2} \mathrm{O}_{3}$ composites might be due to presence of $\mathrm{Al}_{2} \mathrm{O}_{3}$ and high hardness [13]. Palanisamy Pugalenthi et al. [16] researched on $\mathrm{Al} 7075-\mathrm{SiC}-\mathrm{Al}_{2} \mathrm{O}_{3}$ through stir casting. The result showed that the tensile strength and hardness of the composite increased by increasing the wt. \% of reinforcements. The presence of hard particles decreased the wear rate and further the wear rate was reduced by reinforcing with $\mathrm{SiC}-\mathrm{Al}_{2} \mathrm{O}_{3}$ [13]. Marialaura et al. [17] studied the effect of heat treatment on mechanical properties of AlSi3 $\mathrm{Cr}$ alloy. The results revealed that the heat treatment played an important role on intermetallic bonding between the ceramic particles and metal matrix. The mechanical behavior of AlSi3Cr alloy shows remarkable tensile strength in heat-treated conditions compared to untreated conditions. Myriounis et al. [18] investigated the interface effects and heat treatment on the mechanical properties of aluminium matrix composites reinforced with SiC-Particle. The obtained results indicated the T6 heat-treated MMCs with $20 \%$ wt. of SiC particles show the highest strength when compared to the $31 \% \mathrm{wt}$. SiC particles composite. This is predictable since the mechanical strength of the MMCs in the T6 condition originates from the development of the Mg2Si precipitates. Prabhu et al. [19] studied the effect of heat-treatment on mechanical strength and wear behaviour of Al6061 composites reinforced with SiCp. The tensile strength of MMCs composites increases with increasing in SiCp. The heat treatment had a significant effect on ultimate tensile strength of composites. Further, wear rate of MMCs decreases, by increasing in SiCp in the matrix alloy under the tested condition. The heat treatment has a found significant effect on wear behaviour of composites. The detailed literature survey shows that the addition of two different ceramic particulates reinforced in $\mathrm{Al}$ alloy can improve the mechanical properties and wear resistance of Al hybrid MMCs. Though, it has been observed that only few research works has been executed to study the influence of two ceramic particulates reinforcement in Al MMCs. An effort has been made in the present investigation to produce $\mathrm{Al}$ composites by adopting stir casting method under various wt. \% of reinforcement to obtain better mechanical and wear properties. To improve the mechanical and wear properties of developed $\mathrm{Al}$ composites reinforced with $\mathrm{SiC}$ and $\mathrm{Al}_{2} \mathrm{O}_{3}$ heat treatment process has been introduced. In the present study, the performance of the composites enhanced with different types of quenching processes like as-received, water quenched and ice quenched process were carried out on developed composites.

\title{
SELECTION OF MATERIALS AND EXPERIMENTAL PROCEDURES
}

\begin{abstract}
A 17075 having a density $2.7 \mathrm{~g} / \mathrm{cm}^{3}$, was used as a matrix material. $\mathrm{Al}_{2} \mathrm{O}_{3}$ and $\mathrm{SiC}$ were used as reinforcements. Four different weight percentages of $\mathrm{SiC}$ and $\mathrm{Al}_{2} \mathrm{O}_{3}(2 \%, 4 \%, 6 \%$ and $8 \%)$ were chosen in the experiments. The average particle size was $100 \mu \mathrm{m} \mathrm{Al}_{2} \mathrm{O}_{3}$ with ph value of 6.5-7.5. SiC of $220 \mu \mathrm{m}$ mesh size particulates were used in the present investigation. Stir casting method was adopted to fabricate the MMCs. The reinforcement particles which were preheated were mixed with $\mathrm{Al}$ alloy at the time of stirring. Degassing process was adopted to remove the gasses present in molten melt. In the present investigation, the stirring was done at 100-125 rpm for the duration of 5 min, later the molten melt was poured in to pre-heated mold box. After solidification, the cast samples were removed from mold box and machined by CNC. The hybrid MMCs with $\mathrm{Al}$ alloy matrix containing $\mathrm{SiC}$ and $\mathrm{Al}_{2} \mathrm{O}_{3}$ were characterized by heat treatment process and thus their material properties can be improved. The process of heat treatment was chosen based on the nature of the materials and its functions, being defined by temperature $\left({ }^{\circ} \mathrm{C}\right)$, duration and type of cooling medium [20]. Quenching formed a significant part of the heat treatment method. The process included cooling the material after the heat treatment in different mediums and at different cooling speeds [21]. The composite specimens were subjected to solutionizing for a duration of $2 \mathrm{hrs}$ at a temperature of $480^{\circ} \mathrm{C}$ and then quenched separately in two different quenching media such as water and ice cubes. Finally, the age-hardening was carried out at a temperature of $160^{\circ} \mathrm{C}$ for the duration of $4 \mathrm{hrs}$ and then cooled at room temperature $\left(27^{\circ} \mathrm{C}\right)$.
\end{abstract}

\section{RESULTS AND DISCUSSIONS}

Tensile strength

he specimens were prepared according to ASTM E8 standard and the tests were performed on the cast composites. Tensile tests were performed by subjecting the test specimens to axial or longitudinal load at a particular extension rate of load till failure of the specimen occurred. Tests were conducted on the Universal Testing Machine (UTM) whose maximum load capacity is $400 \mathrm{KN}$. Fig. 1 shows the tensile strength of $\mathrm{SiC} / \mathrm{Al}_{2} \mathrm{O}_{3}$ reinforced hybrid metal matrix 
composites. The result shows clearly that the ultimate tensile strength of the MMCs increased by increase in volume percent $\mathrm{SiC}$ and $\mathrm{Al}_{2} \mathrm{O}_{3}$. This outcome is due to the existence of high amounts of ceramic particulates in MMCs [9]. The tensile strength of the MMCs increased due to the resistance of dislocations and therefore the composites strength increased with increase in wt. \% of hard ceramic particulates. The nature of hard ceramic particulates is the cause of the enhancement in strength [16]. The ceramic particles correlate with dislocations which lead to improvement in the tensile strength. Similar outcomes have been observed by different researchers [22-24]. It was observed that there was an improvement in the tensile strength of heat treated MMCs when compared to as received condition. It is revealed that due to heat treatment there is possibility of development of coherent precipitates. The lattice coherency among the base matrix and the precipitates occur up to a certain degree of temperature beyond which the lattice vibration forms the non-coherent precipitates with the base matrix. It is a known fact that throughout the ageing after the solutionizing treatment fine precipitates are formed on the soft Al matrix which results in improving the composite properties [25]. From the results, it was revealed that the tensile strengths of the heat treated composites are higher compared to un-heat treated composites. The improvement in ductility of MMCs can be attributed to the coupling effect of a numerous small hard ceramic particles due to growth restriction and also thermal modification at the time of heat treatment [26]. As shown in Fig. 1, maximum tensile strength was found for the composites when the quenched in ice. This marked enhancement in tensile strength of MMCs studied on heat-treatment can be attributed to high extent of development of intermetallic precipitates, generally, which act as the points of obstacles for the pinning down of dislocations. This phenomenon of multiplication of dislocations limits the mobility of dislocations, thus reducing the level of plastic deformation. This leads to major improvement in tensile strength of MMCs [27]. The tensile stress-strain curves of the composite samples fabricated by the stir casting method are shown in Fig. 2. Stress-strain diagram is plotted for as-received, water quenched and ice quenched samples and all the points are indicated. Out of all these composite specimens, the tensile strength is higher for ice quenched specimen. In order to understand the mode of failure during tensile test, fractographic analysis was carried out on the composite specimens after fracture. The fractographic examination shows that increase in the wt. \% of the $\mathrm{SiC} \& \mathrm{Al}_{2} \mathrm{O}_{3}$ changed the kind of failure from ductile to brittle, which could be evidently observed from the dimples and deformed region present within the area of the fracture [16]. With the increased $\mathrm{SiC}-\mathrm{Al}_{2} \mathrm{O}_{3}$ content, it is observed that multiple micro cracks have occurred signifying decreased ductility. In general, the topology of the fractured surfaces appears with multiple cracks and voids. Formation of voids is caused by the presence of hard ceramic particulates with soft matrix initiating triaxial state of stress in the vicinity of a particle. The void at the interfaces among the particles and matrix increased the crack propagation from their center. The existence of ceramic particles on the fracture surface as well as in micro voids also influenced the mechanical properties by improving the bonding of the matrix and decreased the ductility [28 \& 29]. Tensile fracture specimens in as-received condition were obtained and showed ductile fracture was seen with micro and macro dimples and also cup and cone fracture have been observed. The fracture surface of composites without heat treatment after tensile test specimen is shown in Fig. 3. From the Fig. 3, it is observed that the fracture is mainly dimple rupture. Generally, this is the normally due to the overload failure and failure by merging of micro-voids process. The numerous cuplike despairs are also observed in Fig. 3. Formation and coalescence of micro-voids results in the dimples at localized strain regions (grain boundaries). Fig. 4 shows the fractured surface of water quenched specimen after tensile test. Number of dimples observed is more and in smaller sizes indicating the development of micro-voids. Therefore, it is seen that dimples are equally distributed.

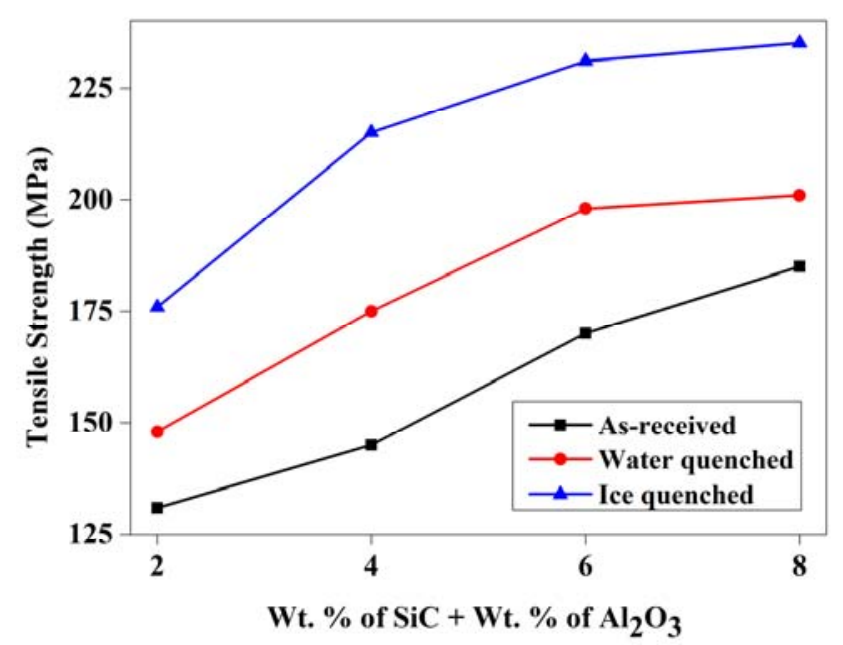

Figure 1: Tensile strength for varying wt. \% of $\mathrm{SiC}$ and $\mathrm{Al}_{2} \mathrm{O}_{3}$. 


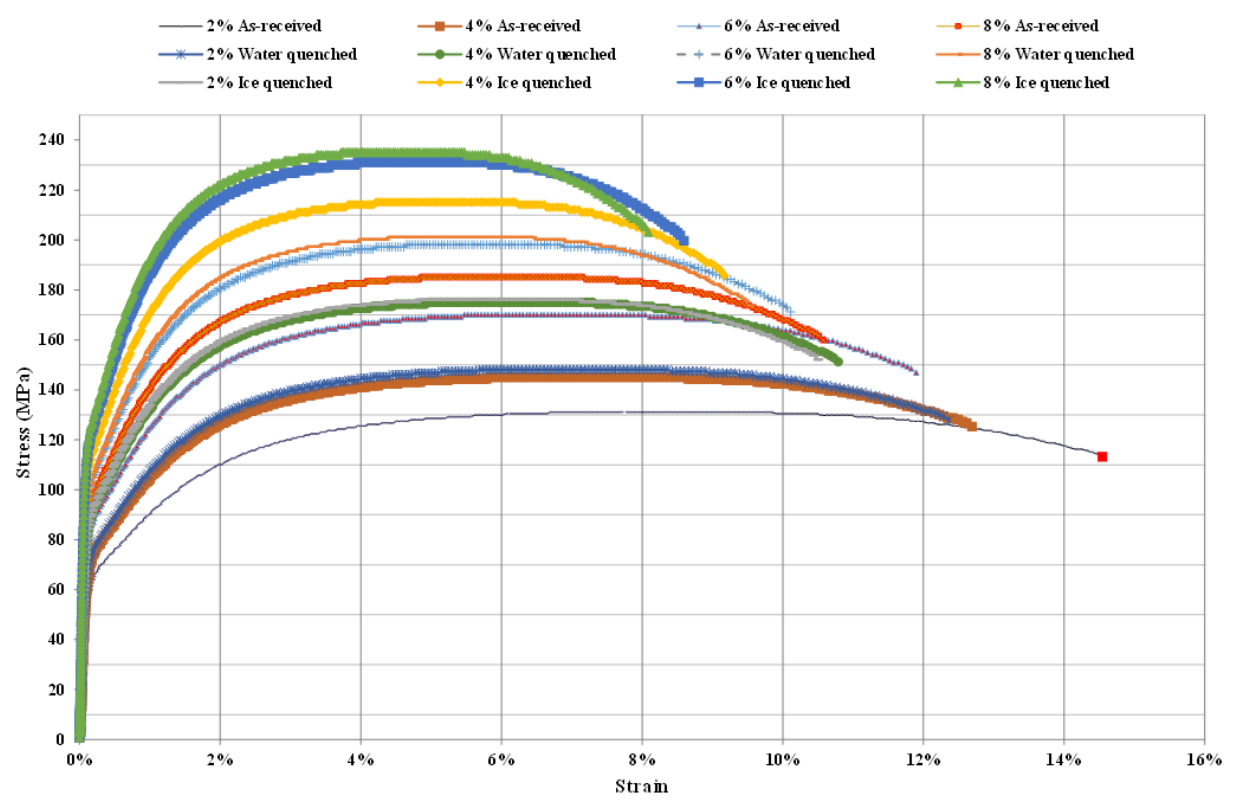

Figure 2: Stress-strain curve for as-received, water quenched and ice quenched samples.

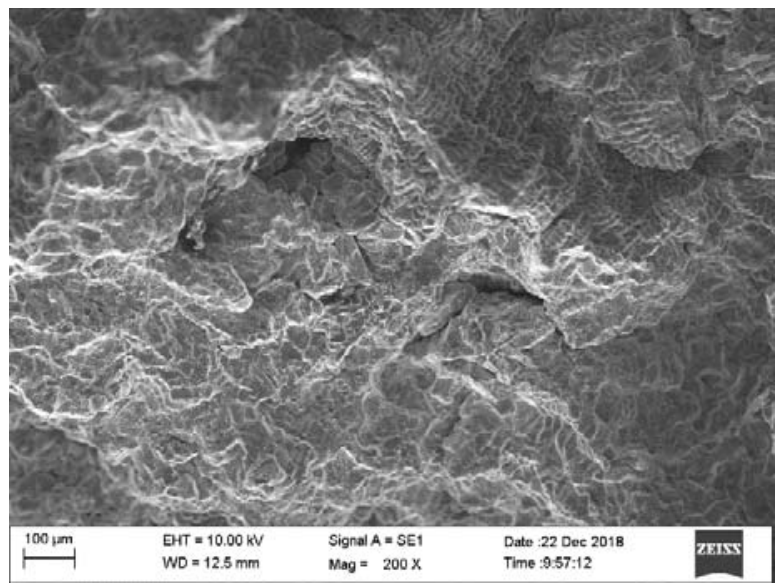

Figure 3: Fracture images of un-heat treated composites.

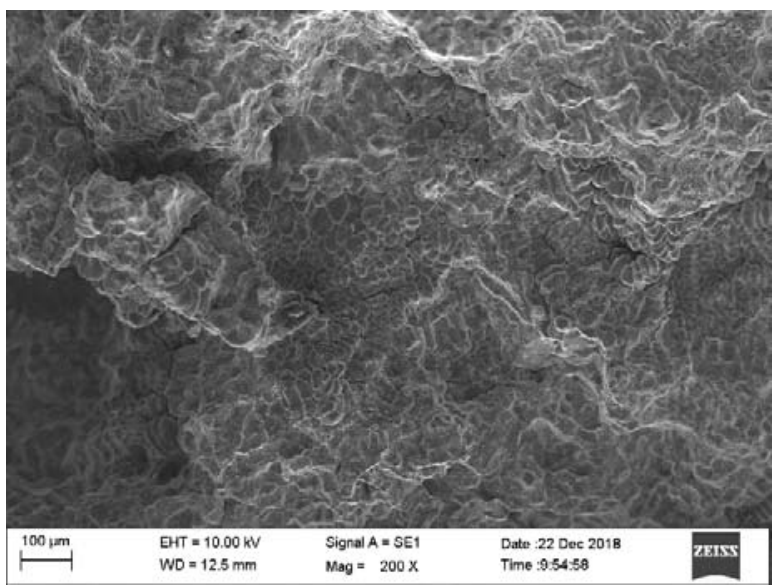

Figure 4: Fracture images of water quenched composites. 

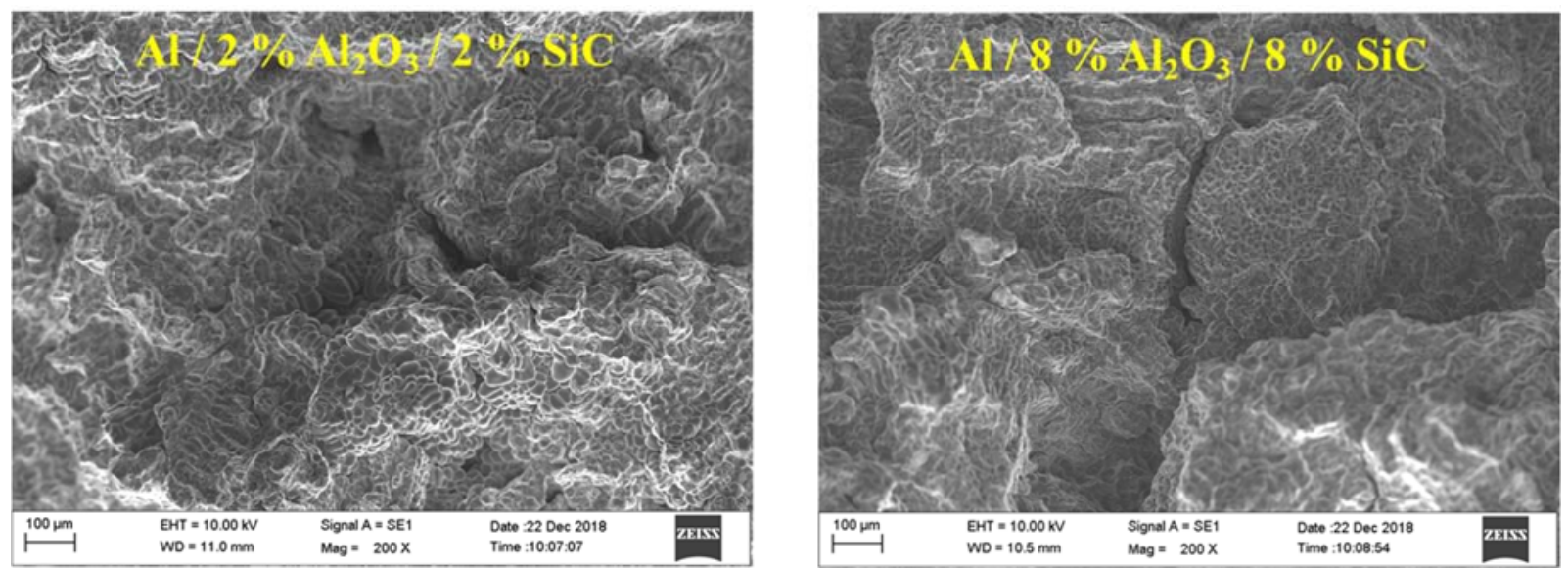

Figure 5: Fracture images of ice quenched composites with different compositions.

The fractography of ice quenched composites obtained using SEM are as shown in the Fig. 5. An investigation of these fracture surface structures as seen in the SEM at high magnification was done to study the fracture region, to detect areas of initiation of micro-crack, growth of early crack and the over-loaded area to identify the satisfactory scale fracture features [28]. The dimples size in the fractured surface of the water quenched specimen is smaller when compared to the fractured surface of the untreated composites. Similarly, ice quenched specimens show smaller size dimples compared to water quenched specimens. Generally, the dimple size shows direct proportional relationship with composite strength.

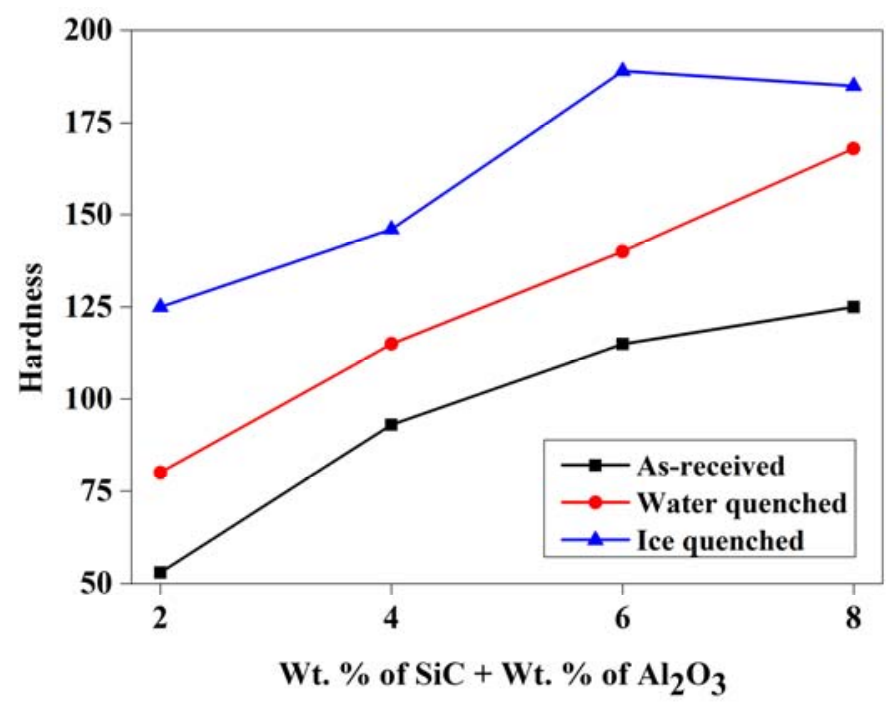

Figure 6: Vickers hardness with varying content of $\mathrm{SiC}$ and $\mathrm{Al}_{2} \mathrm{O}_{3}$.

\section{Hardness}

The hardness of composites were tested according to ASTM E92 standards by using Vickers hardness testing equipment with an indenter of $10 \mathrm{~mm}$ diamond and the load of $1 / 2 \mathrm{~kg}$ for a period of 10 seconds. The test was conducted at room temperature $\left(27^{\circ} \mathrm{C}\right)$ and the hardness value was evaluated at three different places on the samples to obtain the average value of hardness. The effect of $\mathrm{SiC}$ and $\mathrm{Al}_{2} \mathrm{O}_{3}$ on the hardness based on different quenching media is shown in Fig. 6. The hardness of the $\mathrm{Al} 7075 / \mathrm{SiC} / \mathrm{Al}_{2} \mathrm{O}_{3}$ composite increases by addition of $\mathrm{SiC}$ and $\mathrm{Al}_{2} \mathrm{O}_{3}$ content as observed from the Fig. 6. Generally, the hard ceramic particles avoid the motion of dislocations which leads to improvement in the results of hardness [30]. As the hard ceramic reinforcements are added, the hardness is increased, which exhibits more resistance to plastic deformation with in the composite rendering increase in hardness of the composites [31]. Similar outcomes were observed by Rajesh Kumar Bhushan [10] the results conclude that the silicon carbide particles form barricades which hinder the dislocation motion. This causes increase in the hardness of composites. This outcome is in similar agreement with the results 
of Yogesh Kumar Singla et al. [32], resulting the support of the enormous volume of dislocations at the particulates-matrix interface throughout the solidification process due to the low-coefficient of thermal expansion of reinforcing particulates such as $\mathrm{SiC}$ and $\mathrm{Al}_{2} \mathrm{O}_{3}$ compared with $\mathrm{Al}$ is one of the main reasons for increase in hardness values.

The influences of quenching media on hardness have been presented in Fig. 6. It is observed that heat treated samples exhibit higher hardness as compared to non-heat treated samples. The samples which were quenched in ice, show higher hardness compared to as-received and water quenched samples. The solutionizing treatment shows the formation of intermetallic phase which have been observed to be harder than Al leading to higher hardness [20]. In T6 condition of heattreated composites, the thermal mismatching of base matrix and reinforcements thermally promotes the density improvements in dislocation and form towards the advanced resistance to the plastic deformation which leads to better hardness [33]. The ice quenched samples exhibit better hardness which is due to combined effect of improved bonding between the particulates and base matrix due to lower temperature and stabilization of intermetallic phase with in the matrix [20]. High cooling rates caused distortions that might affect the hardness values. This phenomenon affected the distortion which was produced by the dislocation slip and provided the positive effect on the hardness of composites [34].

\section{Wear behavior (Weight loss)}

Wear behaviour of $\mathrm{Al} 7075-\mathrm{SiC}-\mathrm{Al}_{2} \mathrm{O}_{3}$ composites was conducted by using pin-on-disk wear testing equipment under the load of $3 \mathrm{~kg}$ at a sliding speed of $1.66 \mathrm{~m} / \mathrm{s}$ against the EN32 steel disk. Composites specimens of $8 \mathrm{~mm} \phi$ and length of 30 $\mathrm{mm}$ were prepared by machining process. The initial weight of the wear specimens was measured to a least count of 0.0001 $\mathrm{gm}$. After the each test, the specimens were removed, cleaned by using acetone liquid, dried and weighed to measure the weight loss due to wear. Fig. 7 indicates the influence of the weight percentage of $\mathrm{SiC}+\mathrm{Al}_{2} \mathrm{O}_{3}$ particles on weight loss based on different quenching media. From the results it is seen that the wear rate of the composites decreases gradually by increasing the weight percentage of $\mathrm{SiC}$ and $\mathrm{Al}_{2} \mathrm{O}_{3}$ content. This is evidently due to the existence of the hard ceramic particulates and to their immunization effect which results in the fine grain structure [15]. From the outcomes this observation is made that the existence of hard particles decreases the wear rate and the wear rate of $\mathrm{Al}-\mathrm{SiC}$ decreases with increase in of $\mathrm{Al}_{2} \mathrm{O}_{3}$ particles. When the $\mathrm{Al}_{2} \mathrm{O}_{3}$ particulates are intensely bonded with $\mathrm{Al}$ matrix, it helps to protect the surface against destructive action of the counter face which reveals less wear. In case of $\mathrm{Al}$ composites, the depth of dispersion due to harder asperities of high hardened steel disc is essentially governed by the protruded hard ceramic reinforcements. The major portion of the load applied is carried by SiC reinforcement particles. The task of reinforcing particulates is to sustain the contact pressures, preventing from high plastic deformation and graze among the contact surfaces and thus reduce the quantity of wornout materials $[13,35]$. The heat treatment of MMCs has a significant effect on the wear resistance of composites as depicted in Fig. 7. For a constant load and the steel wheel used, ice as a quenching media has resulted in the high wear resistance of heat treated composites when compared to water quenched and as-received composites [27].

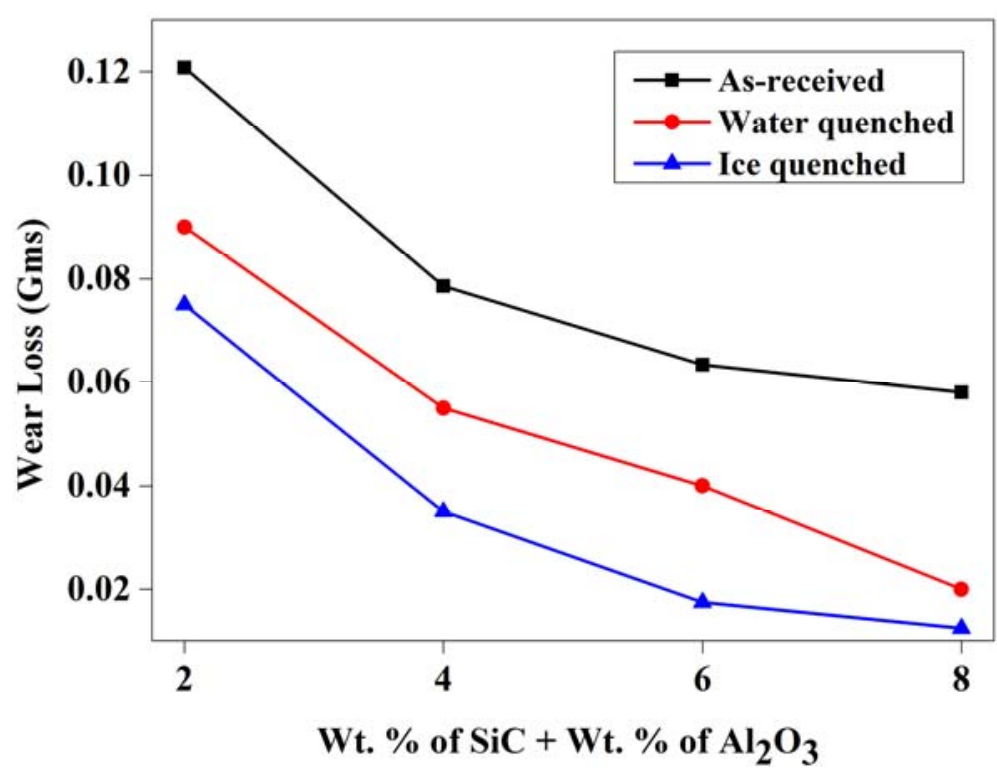

Figure 7: Wear loss with varying content of $\mathrm{SiC}$ and $\mathrm{Al}_{2} \mathrm{O}_{3}$. 
The water quenched composites exhibit the better wear resistance and further ice quenching reduces the high wear rate as shown in the Fig. 7. The heat treated composites show better hardness when compared to the un-heat treated composites. This may be due to the formation of high harder intermetallic phase and quenching with ice further improves the hardness in composites due to the stabilization of the intermetallic phase [20]. Nature of wear resistance varies for both the quenching conditions. In the case of water quenching the wear rate has been decreased drastically for the hybrid composites. Later, the wear rate has decreased more in composites which were quenched in ice cubes. All these show that the heat treatment has a high influence on the wear behaviour of the composites, which can be understood according to similar observations revealed earlier by various investigations [36]. Here, the wear rate of the heat-treated MMCs is less as compared to un-heat treated composites due to the oxide film formed on the composite surface which prevents the metal to metal contact. In heat treated composites, the particles act and restrain severe wear rate [33].

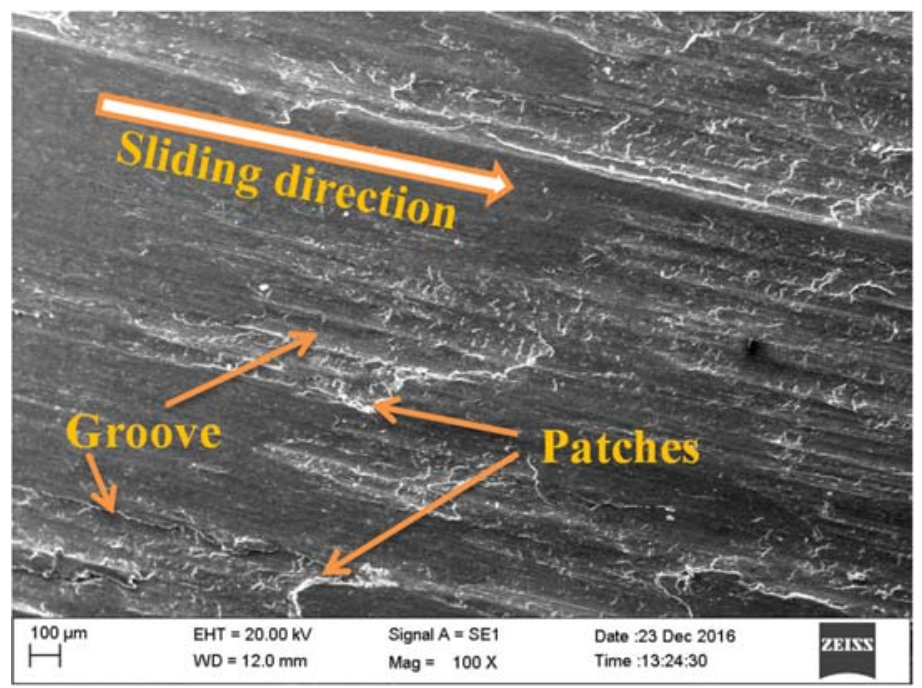

Figure 8: SEM image of the ice quenched ( $\mathrm{Al}-2 \%$ of $\left.\mathrm{Al}_{2} \mathrm{O}_{3}-2 \% \mathrm{SiC}\right)$ composites

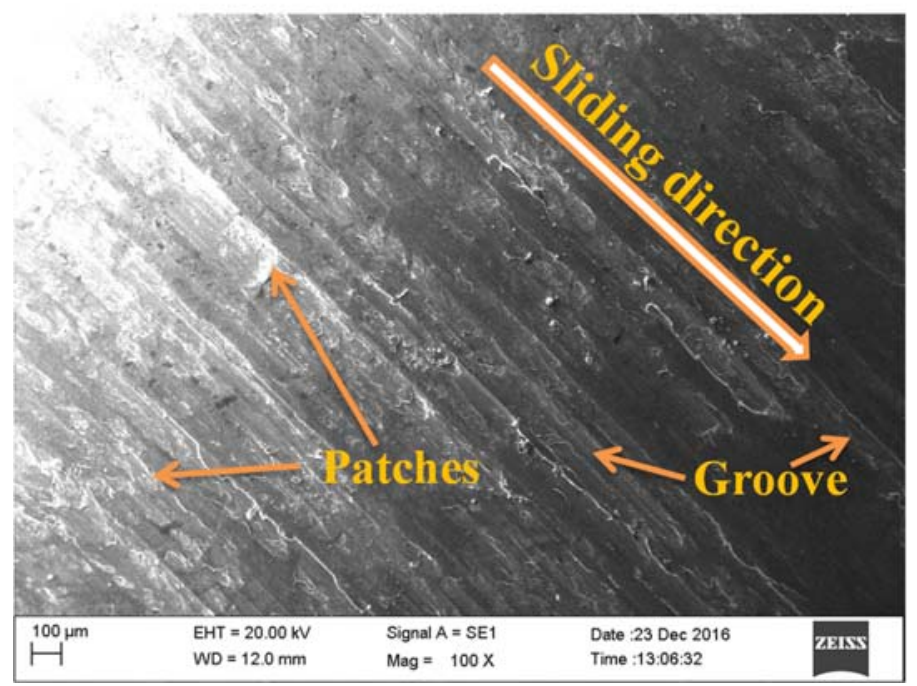

Figure 9: SEM image of the ice quenched ( $\mathrm{Al}-8 \%$ of $\left.\mathrm{Al}_{2} \mathrm{O}_{3}-8 \% \mathrm{SiC}\right)$ composites

To understand the wear mechanisms, the wornout surfaces of the composites specimens corresponding to the weight percentage were examined by SEM analysis. The SEM images of wornout surfaces of the composite specimens with varying wt. \% hard particulates are shown in Fig. 8 and 9. Here, $\mathrm{Al}_{2} \mathrm{O}_{3}$ particles are observed as whitish phases and the SiC particles are observed as dark phases in the composites. The worn morphology of $\mathrm{Al}+2 \%$ of $\mathrm{Al}_{2} \mathrm{O}_{3}+2 \% \mathrm{SiC}$ was revealed scratches and grooves in the deformed areas. The contact between the composite specimen and steel disc was resulting the abrasive wear due to the scratches and parallel grooves on the wornout surfaces. The worn surface of $\mathrm{Al}^{+} 8 \%$ of $\mathrm{Al}_{2} \mathrm{O}_{3}+$ 
$8 \% \mathrm{SiC}$ was showed high wear resistance than other composites. Due to the inter metallic phases the $\mathrm{Al}+2 \%$ of $\mathrm{Al}_{2} \mathrm{O}_{3}+$ $2 \% \mathrm{SiC}$ composites revealed high wear rate. The existence of inter metallic phase have been reduced and ceramic particulates were uniformly distributed in $\mathrm{Al}+8 \%$ of $\mathrm{Al}_{2} \mathrm{O}_{3}+8 \% \mathrm{SiC}$ composite materials. Due to the uniform dispersal of ceramic particulates and existence of low inter-metallic phases of $\mathrm{Al}+8 \%$ of $\mathrm{Al}_{2} \mathrm{O}_{3}+8 \% \mathrm{SiC}$ composite revealed better wear resistance [37]. This remarkable observation is evidence with the results of $[38,39] \mathrm{SiC} / \mathrm{Al}_{2} \mathrm{O}_{3}$ particulates are shown to have valuable effects on the wear properties of these MMCs. The $\mathrm{SiC} / \mathrm{Al}_{2} \mathrm{O}_{3}$ particles are shown to fracture in the smaller pieces which create wear debris particulates. $\mathrm{SiC} / \mathrm{Al}_{2} \mathrm{O}_{3}$ particles may avoid the penetration of the steel disk into the composites and there by protect the aluminum from deforming and finally increase its wear resistance. $\mathrm{SiC} / \mathrm{Al}_{2} \mathrm{O}_{3}$ particulates may be crushed into powders which helps to improve the wear resistance, as observed in the results of wear rate.

The ceramic particulates are initiated within the cavities and it is seen that few particulates have broken down and some of the particles are pulled away from the face. It indicates the rough wear mechanisms which are fundamentally an influence of hard particles exposed on the wornout region. The micrograph reveals that more number of continuous grooves are present on the wornout surfaces. These parallel grooves are the proof of micro ploughing and comparable wornout surfaces with increased severity were found. Wide ploughing can be detected on the wornout surfaces which show prominent wear mechanism in the MMCs. However, in heat-treated MMCs, the wornout surfaces were comparatively smoother with fine grooves and also at the edge of grooves minor plastic deformation was detected in composite. Grooves along the sliding direction and material delamination were detected on the wornout surface of the hybrid MMCs. By increasing the hard ceramic reinforcements the grooves were reduced and also some smooth wear tracks can be seen. Small size grooves were found with oxide patches [33]. The chance of debonding of the particulates due to the continuous sliding causes the particulates to get loosened from the base matrix and get stuck between the surfaces of sliding whereby it might act as abrader leading to short period of wear. This reveals the enhanced wear rate [20]. To study the chemical composition of the $\mathrm{SiC} / \mathrm{Al}_{2} \mathrm{O}_{3}$ reinforced Al composites, Energy Dispersive Spectroscopy (EDS) studies were carried out by using Scanning Electron Microscope (SEM). In Fig. 10, the EDS analysis shows the main composition of $\mathrm{SiC} / \mathrm{Al}_{2} \mathrm{O}_{3}$ reinforced $\mathrm{Al}$ composites such as $\mathrm{Mg}, \mathrm{Si}$, carbon, $\mathrm{Fe}$ and $\mathrm{Al}$ and a small amount of oxygen is also detected. The signals of the oxygen may rise from the presence of the $\mathrm{Al}_{2} \mathrm{O}_{3}$ particulates. These outcomes indicate that the chemical compositions of the $\mathrm{SiC} / \mathrm{Al}_{2} \mathrm{O}_{3}$ reinforced $\mathrm{Al}$ composites are consistent. The presence of carbon shows the addition of $\mathrm{SiC}, \mathrm{Al}_{2} \mathrm{O}_{3}$ particulates with $\mathrm{Al} 7075$ matrix [40].

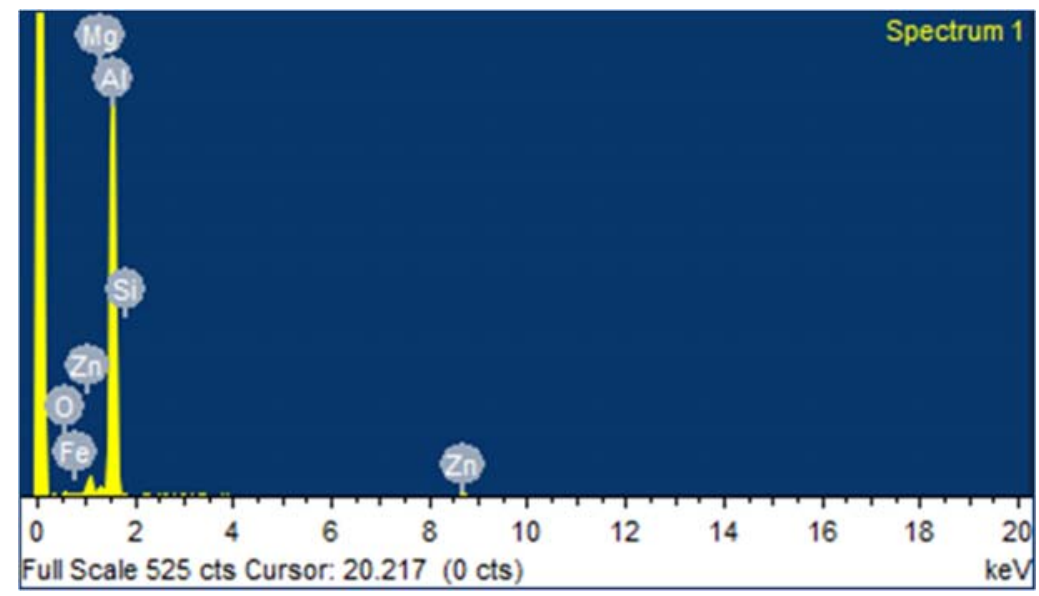

Figure 10: EDS spectrum of wornout surface composite sample ( $\mathrm{Al}+8 \% \mathrm{SiC}+8 \% \mathrm{Al}_{2} \mathrm{O}_{3}$ )

In the chemical compositions of $\mathrm{Al} 7075 / \mathrm{SiC} / \mathrm{Al}_{2} \mathrm{O}_{3}$, oxygen $(\mathrm{O})$ content has been found. The content of " $\mathrm{O}$ " is due to the presence of $\mathrm{Al}_{2} \mathrm{O}_{3}$ as the main compound on the composite surface. The silicon peak in the EDS analysis confirms the presence of $\mathrm{SiC}$ in the composites [40-42]

\section{CONCLUSIONS}

$\mathrm{I}$ $\mathrm{n}$ the investigation, study on the mechanical properties and wear behaviour of $\mathrm{Al} 7075 / \mathrm{SiC} / \mathrm{Al}_{2} \mathrm{O}_{3}$ were evaluated. The Al7075 alloy reinforced by 2, 4, 6 and $8 \mathrm{wt} . \%$ of $\left(\mathrm{SiC}+\mathrm{Al}_{2} \mathrm{O}_{3}\right)$ composites was successfully produced using stir casting process. The outputs have been summarized as follows: 
- The ultimate tensile strength of the MMCs increased by increasing in wt. \% of $\mathrm{SiC}$ and $\mathrm{Al}_{2} \mathrm{O}_{3}$.

- The fractographic studies reveal that the changes in the mode of failure occur from ductile to brittle due to increase in the wt. $\%$ of $\mathrm{SiC} \& \mathrm{Al}_{2} \mathrm{O}_{3}$ content.

- The hardness of the hybrid MMCs increased with increasing in wt. \% of $\mathrm{SiC}$ and $\mathrm{Al}_{2} \mathrm{O}_{3}$ content.

- The maximum tensile strength and hardness of composite was found for the samples quenched in ice.

- The wear rate (weight loss) of the MMCs gradually decreased with increasing in the weight percentage of $\mathrm{SiC}_{\text {and }} \mathrm{Al}_{2} \mathrm{O}_{3}$ content. Higher wear resistance was found at ice quenched samples compared to water quenched samples.

- From the wornout surface, $\mathrm{SiC} / \mathrm{Al}_{2} \mathrm{O}_{3}$ particulates are shown to have valuable effects on the wear properties of composites.

- EDS clearly shows the existence of elemental composition and also revealed the presence of $\mathrm{SiC}$ and $\mathrm{Al}_{2} \mathrm{O}_{3}$ content in the composites.

\section{REFERENCES}

[1] Inegbenebor, A. O., Bolu, C. A., Babalola, P. O., Inegbenebor, A. I. and Fayomi, O. S. I. (2016). Aluminum silicon carbide particulate metal matrix composite development via stir casting processing. Silicon, 10, pp. 343-347.

DOI: $10.1007 / \mathrm{s} 12633-016-9451-7$.

[2] Cao, F., Chen, C., Wang, Z., Muthuramalingam, T. and Anbuchezhiyan, G. (2019). Effects of silicon carbide and tungsten carbide in aluminium metal matrix composites. Silicon, DOI: 10.1007/s12633-018-0051-6.

[3] Omid, Y., Hamid, R. B., Ali, R. A. and Ermia, A. (2018). Development of the properties of Al/SiC nano-composite fabricated by stir cast method by means of coating SiC particles with Al. Silicon, DOI: 10.1007/s12633-018-9867-3.

[4] Riccardo, C. and Maurizio, V. (2014). Metal matrix composites reinforced by nano-particles - A review. Metals, 4, pp. 65-83. DOI: $10.3390 / \operatorname{met} 4010065$

[5] Himanshu, K., Mer, K. K. S., Sandeep, K. (2014). A review on mechanical and tribological behaviors of stir cast aluminum matrix composites. 3rd International Conference on Materials Processing and Characterization (ICMPC 2014), Hyderabad, India, 1951-1960 March.

[6] Yllmaz, O. and Buytoz, S. (2001). Abrasive wear of $\mathrm{Al}_{2} \mathrm{O}_{3}$-reinforced aluminium-based MMCs. Composites Science and Technology, 61, pp. 2381-2392.

[7] Belete, S. Y., Manas, M. M. and Pradeep, K. J. (2013). Influence of reinforcement type on microstructure, hardness, and tensile properties of an aluminum alloy metal matrix composite. Journal of Minerals and Materials Characterization and Engineering, 1, pp. 124-130.

[8] Manu, S., Sandeep, R., Arshad, N. S. and Sachin, M. (2018). Investigation on the effects of silicon carbide and cooling medium during multi-pass FSP of Al-Mg/ SiC surface composites. Silicon, DOI: 10.1007/s12633-018-0037-4.

[9] Subramanya, R. P., Kesavan, R. and Vijaya, R. B. (2017). Investigation of mechanical properties of aluminium 6061silicon carbide, boron carbide metal matrix composite. Silicon, DOI: 10.1007/s12633-016-9479-8.

[10] Rajesh, K. B. and Sudhir, K. (2011). Influence of SiC particles distribution and their weight percentage on $7075 \mathrm{Al}$ alloy. Journal of Materials Engineering and Performance, 20(2), pp. 317-323. DOI: 10.1007/s11665-010-9681-6.

[11] Manoj, S., Deepak, D., Lakhvir, S. and Vikas, C. (2009). Development of aluminium based silicon carbide particulate metal matrix composite. Journal of Minerals \& Materials Characterization \& Engineering, 8(6), pp. 455-467.

[12] Sharma, S. C., Girish, B. M., Rathnakar, K. and Satish, B. M. (1997). Effect of SiC particle reinforcement on the unlubricated sliding wear behaviour of ZA-27 alloy composites. Wear, 213, pp. 33-40.

[13] Surappa, M. K. and Rohatgi, P. K. (1981). Preparation and properties of cast aluminium-ceramic particle composites. Journal of Materials Science, 16, pp. 983-993.

[14] Madeva, N., Bharath, V. and Auradi, V. (2013). Effect of $\mathrm{Al}_{2} \mathrm{O}_{3}$ particles on mechanical and wear properties of $6061 \mathrm{Al}$ alloy metal matrix composites. Journal of Material Sciences \& Engineering, 2(1), pp. 1-4.

[15] Abdel, A. A. N., Shash, Y., Mostafa, S. F. and Younan, A. (1995). Casting of 2024-Al alloy reinforced with $\mathrm{Al}_{2} \mathrm{O}_{3}$ particles. Journal of Materials Processing Technology, 55, pp. 199-205.

[16] Palanisamy, P., Murugesan, J. and Venkatajalapathy, S. (2019). Study of the microstructures and mechanical properties of aluminium hybrid composites with $\mathrm{SiC}$ and $\mathrm{Al}_{2} \mathrm{O}_{3}$. Materials and technology, 53(1), pp. 49-55.

[17] Marialaura, T., Annalisa P., Lorenzo M. and Marina. (2017). Investigation of mechanical properties of AISi3Cr alloy. Frattura ed Integrità Strutturale, 42, pp. 337-351. 
[18] Myriounis, D. P., Hasan, S. T. and Matikas, T. E. (2008). Heat treatment and interface effects on the mechanical behavior of SiC-particle reinforced aluminium matrix composites. Journal of ASTM International, 5(7), pp. 1-13.

[19] Prabhu Swamy, N. R., Ramesh. C. S. and Chandrashekar, T. (2010). Effect of heat treatment on strength and abrasive wear behaviour of Al6061-SiCp composites. Bull. Mater. Sci., 33(1), pp. 49-54.

[20] Reddappa, H. N., Suresh, K. R., Niranjan, H. B. and Satyanarayana, K. G. (2011). Effect of cold quenching on wear rate of Al6061-beryl composites. International Journal of Engineering Science and Technology (IJEST), 3(10), pp. 7309 7315.

[21] Senthilkumar, P. (2018). Effect of quenching media on mechanical properties of 7075 aluminium alloy. International Journal of Science and Research (IJSR), 8(8), pp. 2174-2177.

[22] Shaik, M. Q., Suryanarayana, M. B. and Pinninti, R. R. (2016). Processing and mechanical properties of $\mathrm{Al}_{2} \mathrm{O}_{3}$ and red mud particle reinforced AA6061 hybrid composites. Journal of Minerals and Materials Characterization and Engineering, 4, pp. 135-142.

[23] Jagbir, S., Jawalkar, C. S. and Belokar, R. M. (2019). Analysis of mechanical properties of AMC fabricated by vacuum stir casting process. Silicon, DOI: 10.1007/s12633-019-00338-8.

[24] Huda, A. A. S., Adil, A. M. and Hussain, J. A. (2019). Mechanical and wear behavior of AA7075 aluminum matrix composites reinforced by $\mathrm{Al}_{2} \mathrm{O}_{3}$ nanoparticles. Nanocomposites, 5(3), pp. 67-73.

[25] Sanjay, S. and Ajay, P. (2014). Effect of heat treatment on mechanical behavior and structural response of Al-Si composite. International Journal of Advanced Mechanical Engineering, 4(7), pp. 767-782.

[26] Vembu, V. and Ganesan, G. (2015). Heat treatment optimization for tensile properties of $8011 \mathrm{Al} / 15 \% \mathrm{SiCp}$ metal matrix composite using response surface methodology. Defence Technology, 11, pp. 390-395.

[27] Prabhu S. N. R., Ramesh, C. S. and Chandrashekar, T. (2010). Effect of heat treatment on strength and abrasive wear behaviour of Al6061-SiCp composites. Bull. Mater. Sci., 33(1), pp. 49-54.

[28] Suvarna, R. L. and Kumar, A. (2014). Influence of $\mathrm{Al}_{2} \mathrm{O}_{3}$ particles on the microstructure and mechanical properties of copper surface composites fabricated by friction stir processing. Defence Technology, 10, pp. 375-383.

[29] Hossain, A. and Kurny, A. S. W. (2013). Effect of ageing temperature on the mechanical properties of Al-6Si-0.5Mg cast alloys with $\mathrm{Cu}$ additions treated by T6 heat treatment. Universal Journal of Materials Science, 1(1), pp. 1-5.

[30] Mehdi, R., Nader, P. and Naser, E. (2010). Investigation of particle size and amount of alumina on microstructure and mechanical properties of Al matrix composite made by powder metallurgy. Materials Science and Engineering, A527, pp. 1031-1038.

[31] Dhanalakshmi, S., Mohanasundararaju, N. and Venkatakrishnan, P. G. (2014). Preparation and mechanical characterization of stir cast hybrid $\mathrm{Al} 7075-\mathrm{Al}_{2} \mathrm{O}_{3}-\mathrm{B}_{4} \mathrm{C}$ metal matrix composites. Applied Mechanics and Materials, 592(594), pp. 705-710.

[32] Yogesh, K. S., Rahul, C., Hitesh, B. and Anil, K. (2015). Wear behavior of aluminum alloy 6061-based composites reinforced with $\mathrm{SiC}, \mathrm{Al}_{2} \mathrm{O}_{3}$, and red mud: a comparative study. The Minerals, Metals \& Materials Society, 67(9), pp. 2160-2169.

[33] Rajesh A. M., Kaleemulla, M. K. and Doddamani, S. (2019). Effect of heat treatment on wear behavior of hybrid aluminum metal matrix composites. Tribology in Industry, 41(3), pp. 344-354. DOI: 10.24874/ti.2019.41.03.04.

[34] Hammar, I. A., Eko, S., Dody, A. and Aditya, R. P. (2020). Experimental study of quenching agents on $\mathrm{Al}_{6061}-\mathrm{Al}_{2} \mathrm{O}_{3}$ composite: effects of quenching treatment to microstructure and hardness characteristics. Results in Engineering, 6, pp. 1-8. DOI: $10.1016 /$ j.rineng.2020.100105.

[35] Padmavathi, K. R., Ramakrishnan, R. and Palanikumar, K. (2019). Wear properties of SiCp and $\mathrm{TiO}_{2} \mathrm{p}$ reinforced aluminium metal matrix composites. Indian Journal of Engineering \& Materials Sciences, 26, pp. 51-58.

[36] Reddappa, H. N., Suresh, K. R., Niranjan, H. B. and Satyanarayana, K. G. (2012). Effect of quenching media and ageing time on Al6061-beryl composites. Applied Mechanics and Materials, 110(116), pp. 1374-1379.

[37]Jaya, P. V., Chiranjeevi, R., Santosh, K. R., Venkata, R. and Sunny, K. (2018). Effect of SiC on mechanical, microstructure and tribological properties of aluminum MMC processed by stir casting. IOP Conference Series: Materials Science and Engineering, 455, pp. 1-9. DOI: 10.1088/1757-899X/455/1/012017.

[38] Altinkoka, N., Ozsert, I. and Findik, F. (2013). Dry sliding wear behavior of $\mathrm{Al}_{2} \mathrm{O}_{3} / \mathrm{SiC}$ particle reinforced aluminium based MMCs fabricated by stir casting method. Acta Physica Polonica A, 124, pp. 11-19.

DOI: 10.12693/APhysPolA.124.11.

[39] Umanath, K., Selvamani, S.T., Palanikumar, K. and Dinesh, R. G. (2014). Worn surface analysis of hybrid metal matrix composite. Advanced Materials Research, 984(985), pp. 546-550. 
[40] Rajesh, A. M., Mohamed, K., Saleemsab, D. and Bharath, K. N. (2019). Material characterization of $\mathrm{SiC}_{\text {and } \mathrm{Al}_{2} \mathrm{O}_{3-}-}$ reinforced hybrid aluminum metal matrix composites on wear behavior. Advanced Composites Letters, 28, pp. 1-10. DOI: $10.1177 / 0963693519856356$.

[41] Poovazhagan, L., Kalaichelvan, K., Rajadurai, A. and Senthilvelan, V. (2013). Characterization of hybrid silicon carbide and boron carbide nanoparticles-reinforced aluminum alloy composites. International Conference on Design and Manufacturing, IConDM 2013, 64, pp. 681-689.

[42] Ravikumar, M., Reddappa, H. N. and Suresh, R. (2018). Study on mechanical and tribological characterization of $\mathrm{Al}_{2} \mathrm{O}_{3} / \mathrm{SiCp}$ reinforced aluminum metal matrix composite. Silicon, 10(6), pp. 2535-2545.

DOI: $10.1007 /$ s12633-018-9788-1. 